\title{
A simulation study on the effect of climate change \\ on crop water use and chill unit accumulation
}

AUTHORS:

Abiodun A. Ogundeji

Henry Jordaan ${ }^{1}$

\section{AFFILIATION:}

'Department of Agricultural Economics, University of the Free State, Bloemfontein,

South Africa

\section{CORRESPONDENCE TO: Abiodun Ogundeji}

EMAIL:

ogundejiaa@ufs.ac.za

\section{DATES:}

Received: 20 Apr. 2016

Revised: 19 Sep. 2016

Accepted: 08 Apr. 2017

\section{KEYWORDS:}

water; adaptation; deciduous fruits; management practices; irrigation

\section{HOW TO CITE:}

Ogundeji AA, Jordaan H. A simulation study on the effect of climate change on crop water use and chill unit accumulation. S Afr J Sci. 2017;113(7/8), Art. \#2016-0119, 7 pages http://dx.doi.org/10.17159/ sajs.2017/20160119

\section{ARTICLE INCLUDES:}

$\times$ Supplementary material

$\times$ Data set

\section{FUNDING:}

None
Climate change and its impact on already scarce water resources are of global importance, but even more so for water scarce countries. Apart from the effect of climate change on water supply, the chill unit requirement of deciduous fruit crops is also expected to be affected. Although research on crop water use has been undertaken, researchers have not taken the future climate into consideration. They also have focused on increasing temperatures but failed to relate temperature to chill unit accumulation, especially in South Africa. With a view of helping farmers to adapt to climate change, in this study we provide information that will assist farmers in their decision-making process for adaptation and in the selection of appropriate cultivars of deciduous fruits. Crop water use and chill unit requirements are modelled for the present and future climate. Results show that, irrespective of the irrigation system employed, climate change has led to increases in crop water use. Water use with the drip irrigation system was lower than with sprinkler irrigation as a result of efficiency differences in the irrigation technologies. It was also confirmed that the accumulated chill units will decrease in the future as a consequence of climate change. In order to remain in production, farmers need to adapt to climate change stress by putting in place water resources and crop management plans. Thus, producers must be furnished with a variety of adaptation or management strategies to overcome the impact of climate change.

\section{Significance:}

- $\quad$ Producers must closely monitor the usage of efficient irrigation technology.

- Climate adaptation needs to be anticipated years in advance and will require a transition to different crop species or cultivars or the development of management practices.

- The results of this study will guide producers in the selection of cultivars when re-establishing their orchards.

\section{Introduction}

Climate change and its impact on already scarce water resources are of global importance, but even more so for water scarce countries. The projected increase in temperature in certain regions of the world is anticipated to have an inevitable influence on water availability. ${ }^{1}$ Changes in the supply of water will inevitably affect the availability of water for domestic use, agricultural production, and industrial use. The water demand pressure, driven by global temperature surges, population growth, degradation of water quality, lack of efficient water management and the like, accentuates water scarcity. ${ }^{2}$ According to the Intergovernmental Panel on Climate Change, by 2020, it is anticipated that about 250 million people will be exposed to water stress because of the changing climate. Combined with an increase in demand, the adverse effect on livelihoods and the aggravation of already existing population shifts, uneven wealth distribution and related problems can lead to a more complicated system.

The unprecedented levels of climate change predicted will have repercussions for climate-sensitive systems (forestry, natural resources and agriculture) around the world. Projected changes in temperature, solar radiation and precipitation could impact on the productivity of both crop and livestock farming. Such changes also have economic impacts on agriculture leading to changes in prices, farm profitability, trade and regional comparative advantage. For an arid and water scarce country such as South Africa, the effects would be more noticeable. In addition, the competitiveness of agriculture may be at risk. Changes in hydrological regimes will also affect the availability of water for irrigation purposes. In addition, future competition for water by non-agricultural users will increase because of population and economic growth.

Climate change is also expected to have an impact on future winter chill, which could potentially have a major impact on fruit species with chilling requirements. ${ }^{3}$ Fruit trees, such as apricots, apples, pears and nectarines, need to achieve a chilling requirement in order to break dormancy in winter and recommence growth in spring. If the winter chill is not sufficient or fulfilled, dormancy is not broken (which occurs in extreme situations) and fruit yields and fruit quality can be severely affected. ${ }^{4}$ If winter chill reduction occurs because of the changing climate, production restraints are expected to set in, because fruit trees might not even undergo or experience their minimum chilling requirement to break dormancy. ${ }^{5}$ This leads to trees developing some physiological symptoms relating to insufficient chill: (1) reduced fruit set and enlarged buttoning, (2) delayed foliation and (3) reduced fruit quality. ${ }^{6}$ It also disrupts spring growth, leading to inconsistent bud break and leaf development, and non-consistent fruit growth. ${ }^{7}$ These physiological symptoms subsequently affect the yield and quality of the fruit. Thus, failure to accumulate the required chill units may have a significant effect on the productivity of such trees as well as the economy of the production region, and even the country.

Research on water use of crops has received much attention in the recent past, ${ }^{8-10}$ but very few studies have considered future climate. Attention has been paid to increased temperature, but most studies in the field ${ }^{11,12}$ to date have failed to relate temperature to chill unit accumulation. The aim of this study was to estimate the changes in crop water requirements as well as chill unit accumulation of deciduous fruit crops in a changing climate. The findings will assist in the decision-making process for adaptation and in the selection of appropriate future cultivars of crops 
and deciduous fruits under the predicted climate change scenarios. After orchards are established, they remain in production for years; therefore the consideration of future expected winter chill is indispensable in times of looming climate change. The accurate quantification of the 'coldness' of winter using phenological models can therefore assist farmers with a relatively complete assessment of how particular cultivars fare under the current conditions, which facilitates cultivar choice. Accurate models can also help researchers measure the impact of various climate change possibilities on fruit production in the fruit producing areas in order to adapt orchard practices accordingly.

Crop water requirement was modelled for current and future climate for two irrigation systems (sprinkler and drip) to establish how climate change will influence water use of fruit crops. Similarly, chill unit accumulation was modelled using the dynamic model for both the present and future climate. The application of the models was demonstrated in an important fruit producing area. In this study, we consider Ceres - an important fruit and crop producing area in South Africa. Fruits and fruit concentrates produced in Ceres are exported to more than 84 countries in Africa, North America, Europe, the Far East, the Middle East and Asia. The production of crops, vegetables and fruits vital for healthier global diets is being threatened by climate change and any changes in the status quo because of projected climate change will destabilise global supply (trade) with an inevitable impact on the production economy. Maintaining and increasing an exporting nation portion of global fruit markets is vital for long-term economic relevance in providing jobs and a reliable source of income for the producers.

\section{Study area and methodology}

\section{Study area}

The Western Cape of South Africa is traditionally the major fruit production province. The province also has the largest concentration of fruit growers with more than $74 \%$ of the total area planted to deciduous fruit. Ceres is an important fruit production region in the Western Cape and has 46251 inhabitants. Ceres is an important agricultural area bounded by fruit exporting farmers. Of all the pear producing regions in the country, the Ceres region has the highest potential. The fact that Ceres produces almost half of the total pear production in South Africa reflects its favourable conditions. Ceres is thus important to the Western Cape economy and the country as a whole because of the strong agriculturebased industry and services. The climate in Ceres is characterised by a major temperature variation between the summer maximums and the winter minimums.

\section{Downscaling of global climate models}

The empirically downscaled data from various global climate models (GCMs) include daily minimum and maximum temperature and rainfall. Agricultural impacts occur at more local scales; outputs from the global scale GCMs have to be downscaled to a suitable finer-scale resolution. The empirical downscaling of values to climate station level used in this study, was undertaken by the University of Cape Town's Climate System Analysis Group. The climate change scenarios were developed for the 'present' (1971-1990) and 'intermediate future' (2046-2065). The period 2046-2065 was chosen because the hydrological impacts of climate change are more evident in the intermediate future (mid-century). Various methods have been developed, including the SOMD (selforganising map-based downscaling) developed at the University of
Cape Town which was used in this study. Details of the method can be found in the study by Hewitson and Crane ${ }^{13}$.

\section{Ceres deciduous fruits and chill units requirements}

Fruit and nut tree species cultivated in South Africa which originated from the cool subtropical and temperate regions require winter chill to ensure homogeneous flowering, satisfactory fruit setting, and economically satisfactory yields. ${ }^{5}$ Table 1 presents four main cultivars of deciduous fruit typically planted in the Ceres region, with their associated winter chill requirement to break dormancy. The chill units are available in Richardson unit because most of the farmers and industry experts in this region record in Richardson unit. These chill requirements are location specific and in this case the ones for the study area are presented. The selection of these four cultivars was based on a 2012 tree census.

In Table 1, the Richardson chill unit requirements for apple cultivars Golden Delicious and Top Red are 1400 Richardson chill unit (RCU). Apples require a higher chill unit than do the other deciduous fruit types presented in Table 1 . The chill unit requirement for pears ranges between 850 RCU and 1200 RCU. The Williams Bon Chretien pears cultivar has the highest chill unit requirement of $1200 \mathrm{RCU}$. Other deciduous fruits such as nectarines, apricots and plums have relatively moderate chill unit requirements. Considering the long life span of deciduous fruit in comparison with annual crops and the huge investment required for their establishment, growers of deciduous fruit crops are particularly vulnerable to changes or the absence of the required chill unit.

\section{Impact of climate change on crop water requirement}

The development of water balance and crop models and the impact of these models on production have been reviewed. ${ }^{14}$ Models such as Agricultural Catchment Research Unit (ACRU), CANE-GRO, CERES, PUTU, SAPWAT and SWB were considered in the review. Of all the models considered, SWB ${ }^{15}$ and SAPWAT ${ }^{16}$ are easily assessable. SWB is a crop growth simulation model that was specifically developed to improve real-time irrigation scheduling. ${ }^{17}$ SWB adoption has been relatively slow and the user base is still very small because it is cumbersome to set up the model and to simulate predefined irrigation schedules.

SAPWAT ${ }^{16}$ was used to estimate crop water requirements for the base or observed climate (1971-1990) and for the intermediate future climate (2046-2065). It is a further development of CROPWAT and is used to estimate irrigation requirements of crops under varying crop production approaches and climates. The present and future periods are of the same duration for easy comparison. SAPWAT was developed as a planning and management tool for the estimation of crop water requirements by irrigation engineers, agriculturists, managers and farmers in South Africa. ${ }^{16}$

SAPWAT is founded on internationally acknowledged principles of estimating crop water requirements; as a result, the user base is large. Furthermore, government considers it a tool to benchmark lawful water use under the National Water Act (Act 56 of 1998). It is easy to use the model because it is supplied with weather data and a unique set of crop parameters specific to South Africa. ${ }^{17}$ In addition, the crop varieties database in SAPWAT is extensive and it has provision for tree and deciduous crops which is not common in other models. SAPWAT uses the Koppen climate system ${ }^{18}$ for calculating crop coefficients and will therefore make it widely acceptable ${ }^{14}$.

Table 1: Selected fruit types in Ceres and Richardson chill unit (RCU) requirements

\begin{tabular}{l|c|l|c|l|l|l|l|l|l}
\hline \hline \multicolumn{1}{c|}{ Apples } & RCU & \multicolumn{1}{|c|}{ Pears } & RCU & \multicolumn{1}{|c|}{ Apricots } & RCU & Nectarines & RCU & Plums & RCU \\
\hline Golden Delicious & 1400 & Forelle & 850 & Soldonne & 650 & August Red & 650 & Angeleno & 400 \\
\hline Top Red/ Starking & 1400 & Williams Bon Chrétien & 1200 & Bebeco & 700 & Fantasia & 600 & Southern Belle & 600 \\
\hline Royal Gala & 1200 & Packham's Triumph & 900 & Ladisun & 500 & Flamekist & 700 & Fortune & 400 \\
\hline Granny Smith & NA & Abate Fetel & 850 & Suaprieight & 450 & Summer Bright & 550 & African Delight & 250 \\
\hline
\end{tabular}


An artificial weather station (i.e. a subset of the original weather station that was reparametrised based on future climate projection) was built into SAPWAT to calculate crop water requirements for the intermediate future in the absence of any information to that effect. It is hypothesised that with climate change, crop water requirements will increase. Two different types of irrigation technologies - drip and sprinkler irrigation systems - were considered and analysed. These are the most common types used in the Ceres region.

SAPWAT uses the basic methodology proposed in FAO- $56^{19}$ in its calculation of crop water requirements utilising the reference evapotranspiration rate $\left(\mathrm{ET}_{\mathrm{o}}\right)$ and the crop coefficient $\left(\mathrm{K}_{\mathrm{c}}\right)$. In order to get the crop water requirement, the calculated reference evapotranspiration (ET) needs to be linked to the crop for which a water requirement is to be determined. ${ }^{16}$ This is achieved through the use of a crop coefficient $\left(K_{c}\right)$ that is defined for each of the four growth stages of the crop, then the sum gives an estimated crop water requirement or crop evapotranspiration $\left(E T_{c r o p}\right) \cdot{ }^{16,19} \mathrm{~K}_{\mathrm{c}}$ relates the water use of specific crops to $\mathrm{ET}_{0}$. This approach takes into consideration the fact that trees need different amounts of water throughout their annual cycle. The mathematical representation is:

$\mathrm{ET}_{\text {crop }}=\mathrm{K}_{\mathrm{c}}{ }^{*} \mathrm{ET}_{0}$

Equation 1

SAPWAT ${ }^{19}$ makes use of the dual crop coefficient approach. The crop coefficient $\left(K_{c}\right)$ is subdivided into smaller components: a basal crop coefficient $\left(\mathrm{K}_{\mathrm{cb}}\right)$ and an evaporation coefficient $\left(\mathrm{K}_{\mathrm{e}}\right)$ as has been identified by expert consultation in Rome. ${ }^{20}$ Equation 1 then becomes Equation $2^{16}$.

$\mathrm{ET}_{\text {crop }}=\left(\mathrm{K}_{\mathrm{cb}}+\mathrm{K}_{\mathrm{e}}\right) \mathrm{ET}_{0}$,

Equation 2

where $\mathrm{ET}_{\text {crop }}$ is crop evapotranspiration (mm/day), $\mathrm{ET}_{0}$ is reference evapotranspiration ( $\mathrm{mm} /$ day), $\mathrm{K}_{\mathrm{cb}}$ is the basal crop coefficient and $\mathrm{K}_{\mathrm{e}}$ is the soil evaporation coefficient. Detailed information on the calculation of crop evapotranspiration is available in SAPWAT's user manual. The value of $K_{c b}$ is read from the table entitled 'Cropdetail' which gives growing period lengths and $K_{c b}$ values for different crops, while $K_{e}$ is calculated from weather data.

The total volume of water that can evaporate from a soil surface is influenced by soil water content, soil characteristics and canopy cover. SAPWAT uses monthly or daily weather data as a basis for calculating daily Penman-Monteith reference evapotranspiration $\left(\mathrm{ET}_{0}\right)$ values for a site, as described by Allen et al. ${ }^{19}$ Weather data in SAPWAT come from five possible sources: CLIMWAT, manual weather stations, automatic weather stations, and user's own weather station data or imported data from external sources. ${ }^{16}$ SAPWAT included the full set of CLIMWAT data, as well as 50 years' daily data for each quaternary drainage region of the country, ${ }^{21}$ and the daily value for some standard and automatic weather stations.

Using the already built-in weather data information, climate station, soil type and relevant irrigation technologies, the crop water requirement for the base period was estimated for selected fruit crops. The H1OC quaternary weather station data was used for the estimation of crop water requirements. This weather station is the closest to the Ceres dam (main source of water supply) and to the farms in the region.

In order to estimate irrigation crop water requirements for the future, an artificial weather station called ' $\mathrm{H} 10 \mathrm{C}$ post climate' was created in SAPWAT. Future relative (\%) changes in mean annual rainfall, mean annual temperature, and change in the Penman-Monteith reference potential evaporation for the 'high' and 'low' GCMs, based on the A2 emission scenario by Schulze ${ }^{22}$, were used. These scenarios represent two of the five climate models ('high' = ECHAM5/MPI-OM; 'low' = IPSLCM4) used in the 'average of models' approach adopted. ${ }^{22}$ The future relative changes (\%) are presented in Table 2. Using the information presented in Table 2, the artificial weather station created was utilised to estimate crop water use for future climate. The 2046-2065 data are a representative of the mid-century data.
There will be a general increase in temperature in the Western Cape in the future. ${ }^{12}$ Figure 1 presents the projected temperature anomalies. ${ }^{12}$ The increase in temperature will result in higher evaporation and possibly result in lower run-off. The average temperature in the Western Cape is projected to increase by approximately $1-2^{\circ} \mathrm{C}$ in the mid-century.

Table 2: Future projected change in climate parameters for $\mathrm{H} 10 \mathrm{C}$ station

\begin{tabular}{l|c|c|c}
\hline \hline & $\begin{array}{c}\text { Change in mean } \\
\text { annual rainfall }\end{array}$ & $\begin{array}{c}\text { Change in mean } \\
\text { annual temperature }\end{array}$ & $\begin{array}{c}\text { Change in Penman- } \\
\text { Monteith reference } \\
\text { potential evaporation }\end{array}$ \\
\hline Low & $+10 \%$ & $+20 \%$ & $+11 \%$ \\
\hline High & $+8 \%$ & $+12 \%$ & $+7 \%$ \\
\hline
\end{tabular}

\section{Impact of climate change on chill unit accumulation}

Temperature during winter affects the development and growth of the buds of deciduous fruit, even though this might not be visible from the outside during the dormant period. ${ }^{23}$ Temperatures during winter can also influence flower quantity and quality, the timing and abundance of flowering. ${ }^{23}$

Chill unit models provide information on how cultivars fare under the current and future climate conditions, inform producers of the stage of phenological development during the growing season and prediction of maturity dates which improve market delivery of fruits. Three important monitoring systems for chill units have been commonly applied: the Utah (Richardson) model ${ }^{24}$ measuring RCU, the Infruitec model (daily positive Utah model) measuring Infruitec chill units and the dynamic chill model ${ }^{25,26}$ measuring dynamic chill portion (DCP). Studies on winter chill and chilling requirements often implicitly assume that all models can be used interchangeably because the choice of model is not important. ${ }^{27}$ However, many studies have shown that the choice of model is very important. ${ }^{28}$

The Richardson and Infruitec models accumulate in a similar manner; the accumulation table is set out in Table 3. The Utah model allocates chilling units for each hour at a given temperature, with temperatures between $2.5^{\circ} \mathrm{C}$ and $9.2^{\circ} \mathrm{C}$ being the most conducive for chill unit accumulation (Table 3). Richardson suggests that the full chill unit can be acquired when the temperature in an hour is between $2.5^{\circ} \mathrm{C}$ and $9.2^{\circ} \mathrm{C}$. This model has been approved by the South African deciduous fruit industry in the southwestern Cape. ${ }^{29}$ High temperatures and temperatures below $0{ }^{\circ} \mathrm{C}$ are not effective for chilling. Higher temperatures in some models neutralise the positive effects of chilling and negative chill units are applied when temperatures surpass the threshold or when they are lower than the threshold. ${ }^{24}$

Table 3: Accumulation table for Richardson and Infruitec chill unit models

\begin{tabular}{c|c|c}
\hline \hline Temperature $\left({ }^{\circ} \mathbf{C}\right)$ & Richardson units & Infruitec units \\
\hline$<1.4$ & 0 & 0 \\
\hline $1.5-2.4$ & 0.5 & 0.5 \\
\hline $2.5-9.1$ & 1 & 1 \\
\hline $9.2-12.4$ & 0.5 & 0.5 \\
\hline $12.5-15.9$ & 0 & 0 \\
\hline $16-18$ & -0.5 & 0 \\
\hline$>18$ & -1 & 0 \\
\hline
\end{tabular}

Sources: Hacking ${ }^{41}$, Zhang and Taylor ${ }^{42}$ 
$\mathrm{a}$
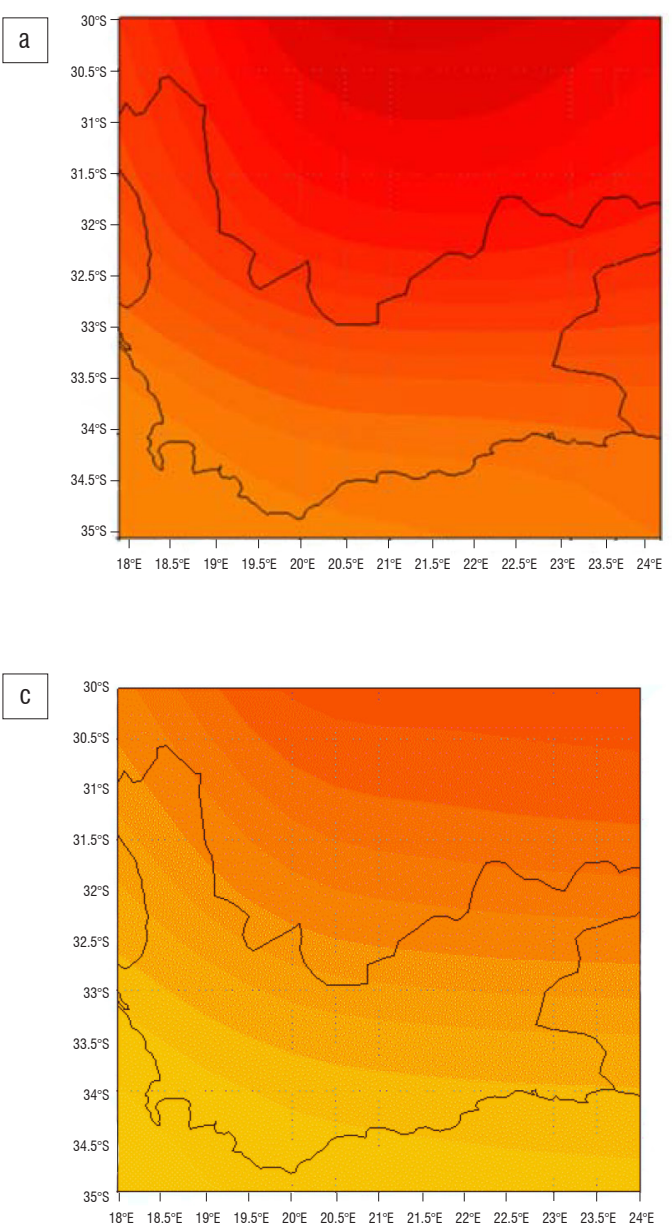
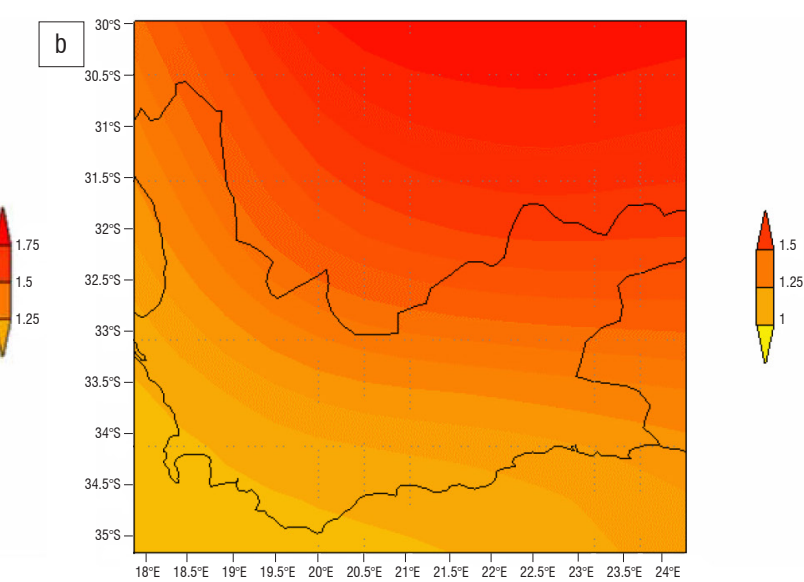

$\mathrm{d}$

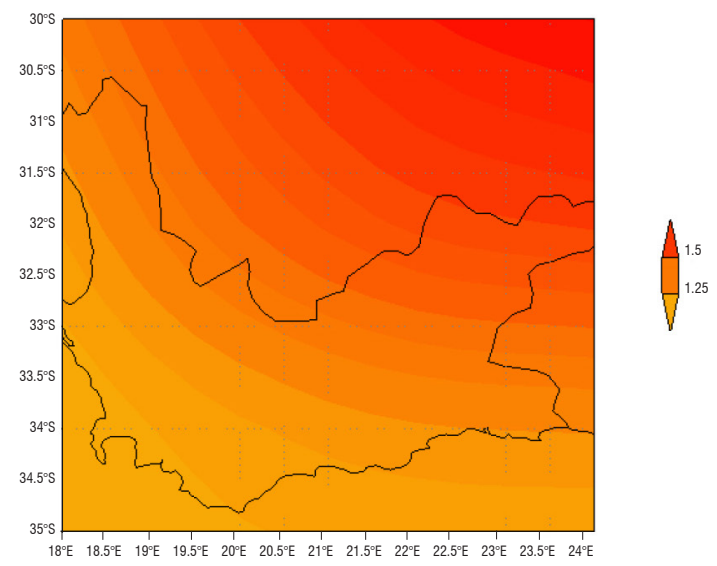

Figure 1: Projected temperature anomalies for the Western Cape, South Africa: (a) December-February, (b) March-May, (c) June-August and (d) SeptemberNovember.

The Infruitec model calculates chill units by making use of the average temperature for each hour, added together every $24 \mathrm{~h}$. In a situation in which the total for the 24-h period is negative, it is taken as zero, but if the total is positive, it is added to the monthly total. This is important in warm growing regions in order not to miss important effects and introduce the risk of the model failing when simulating warming scenarios. Originally, these units were called 'modified Utah chill units'30,31, then 'positive daily Richardson units', and finally 'daily positive Utah chill units'29. This model has been established to give a more precise estimate of winter chilling in regions with mild winters, as well as in areas suffering from very cold winters. ${ }^{32}$

The dynamic mode $\left.\right|^{25,26}$ was introduced in the 1980 s as a new concept for the negation process ${ }^{32}$. This model is based on the premise that winter chill accumulates as a result of a two-step process. In the first step, the cold temperatures initially result in the formation of an intermediate chilling product. This process is reversible, and the intermediate product can be destroyed by high temperatures. Once a critical amount of this chilling product has accumulated, it converts to a chill portion, which cannot be destroyed or reversed. The dynamic model is unique in a number of ways: (1) the importance given to the sequence of temperatures during the cold season ${ }^{28}$; (2) the explanation of the observed negative effect of high temperatures ${ }^{28,33,34}$; and (3) the limit to the quantity of chill that can be reversed ${ }^{35}$.

A review of the literature shows that the dynamic model is the most plausible model - more complex but also more accurate. ${ }^{28}$ The 'chilling hours approach' is very sensitive to temperature increases, and has been found to perform poorly, especially in warm growing regions. ${ }^{28}$
All the models (Richardson, Infruitec and dynamic) have been applied in South Africa ${ }^{36-38}$ and the dynamic model has been found to produce good and consistent results ${ }^{28}$. Based on this justification, we adopted the dynamic model to estimate accumulated chill portion for major fruit crops in Ceres.

The models make use of hourly temperature data to calculate accumulated chill units or portion. Hourly temperature data are not available for the base period. Available for use in this study is the daily maximum and minimum temperature. The sine curve mathematical formula is used to convert daily maximum and minimum temperature data to hourly data, thereby attempting to simulate a sinus curve of hourly data, derived from daily maximum and minimum data values.

The temperature curve shape responds to the daytime solar cycle, and the temperature wave from sunrise to sunset can be described by Equation $3^{7}$ :

$\mathrm{T}(t)=(\operatorname{Tmax}-\mathrm{Tmin})^{*} \sin \left[\frac{(\pi t)}{(D+4)}\right]+\mathrm{Tmin}$

Equation 3

In order to define night-time cooling, starting at sunset, Equation $4^{7}$ is used, given as:

$\mathrm{T}(t)=\mathrm{Tss}-\left[\frac{(T s s-T m n)}{1 \mathrm{n}(24-D)}\right] \ln (t)$,

Equation 4

where $\mathrm{T}(t)$ is temperature at time $t$ after sunrise or at time $t$ after sunset, Tmax is maximum temperature, Tmin is minimum temperature, $D$ is day length (in hours) and Tss is temperature at sunset. 
The calculated $\mathrm{T}(t)$ is used to estimate the accumulated chill units. Change in mean annual temperature, as presented by Schulze ${ }^{22}$, is used to adjust the base temperature for the estimation of future accumulated chill units. H10C quaternary weather station data in SAPWAT were extracted for calculation of accumulated chill units. Apart from the horticultural models, other modelling approaches have been proposed. ${ }^{39,40}$ However, these models have not been extensively applied on fruit trees. ${ }^{28}$

\section{Results and discussion}

\section{Impact of climate change on crop water requirement}

Table 4 presents the results of the crop water requirements from SAPWAT for both the low and high GCMs. The results show that water requirements will increase substantially for both types of irrigation, with both low and high GCMs following a similar trend. Table 4 indicates that the crop water requirements for fruit crops range between $2830 \mathrm{~m}^{3} / \mathrm{ha}$ and $4130 \mathrm{~m}^{3} /$ ha for sprinkler irrigation in the base climate while that for the future climate ranges between $3400 \mathrm{~m}^{3} / \mathrm{ha}$ and $4880 \mathrm{~m}^{3} / \mathrm{ha}$ for low GCM and between $3280 \mathrm{~m}^{3} / \mathrm{ha}$ and $4690 \mathrm{~m}^{3} / \mathrm{ha}$ for high GCM. In the case of drip irrigation, the values are smaller with the base climate crop water requirement ranging between $1950 \mathrm{~m}^{3} / \mathrm{ha}$ and $2900 \mathrm{~m}^{3} / \mathrm{ha}$, while that for future climate ranges between $2320 \mathrm{~m}^{3} / \mathrm{ha}$ and $3390 \mathrm{~m}^{3} / \mathrm{ha}$ for low GCM and between $2190 \mathrm{~m}^{3} / \mathrm{ha}$ and $3280 \mathrm{~m}^{3} / \mathrm{ha}$ for high GCM. Of all the fruit crops considered, peaches use the most water - both in the present and projected future climates.

Table 4: Estimated crop water requirement $\left(\mathrm{m}^{3} / \mathrm{ha}\right)$ for the base and future climate of Ceres

\begin{tabular}{|c|c|c|c|c|c|c|c|}
\hline & \multirow[b]{2}{*}{ Crop option } & \multicolumn{3}{|c|}{ Sprinkler irrigation } & \multicolumn{3}{|c|}{ Drip irrigation } \\
\hline & & Base & $\begin{array}{c}\text { Future } \\
\text { (low) }\end{array}$ & $\begin{array}{l}\text { Future } \\
\text { (high) }\end{array}$ & Base & $\begin{array}{c}\text { Future } \\
\text { (low) }\end{array}$ & $\begin{array}{r}\text { Future } \\
\text { (high) }\end{array}$ \\
\hline \multicolumn{8}{|l|}{ Fruit } \\
\hline Apples & $\begin{array}{l}\text { Bud break: } \\
\text { Mid spring }\end{array}$ & 2980 & 3510 & 3320 & 2110 & 2510 & 2390 \\
\hline Apricots & $\begin{array}{l}\text { Bud break: } \\
\text { Early spring }\end{array}$ & 2830 & 3400 & 3280 & 1950 & 2320 & 2190 \\
\hline Pears & $\begin{array}{l}\text { Bud break: } \\
\text { Late winter }\end{array}$ & 3980 & 4690 & 4470 & 2790 & 3320 & 3180 \\
\hline Nectarines & $\begin{array}{l}\text { Bud break: } \\
\text { Mid spring }\end{array}$ & 3480 & 4090 & 3890 & 2350 & 2780 & 2650 \\
\hline Peaches & $\begin{array}{l}\text { Bud break: } \\
\text { Mid spring }\end{array}$ & 4130 & 4880 & 4690 & 2900 & 3390 & 3280 \\
\hline Grapes & $\begin{array}{l}\text { Bud break: } \\
\text { Mid spring }\end{array}$ & 2870 & 3410 & 3310 & 2170 & 2550 & 2460 \\
\hline Plums & $\begin{array}{l}\text { Bud break: } \\
\text { Early spring }\end{array}$ & 3390 & 3950 & 3790 & 2180 & 2580 & 2480 \\
\hline
\end{tabular}

In general, Table 4 shows that water use for drip irrigation is less than that for sprinkler irrigation because of efficiency differences in the irrigation systems, with less water applied during drip irrigation.

Crop water requirement (or water use) is dependent on the cultivar of each crop chosen, as cultivar differences also play a major role. Apart from cultivar, planting density and other management practices also play significant roles in determining crop water requirement. Table 4 shows that crop water requirements will increase as a result of projected climate change. The change can be attributed to the increase in temperature projected for the future. The crop with the highest deviation from the base climate in both irrigation systems is apricot ( $20 \%$ for sprinkler irrigation and $19 \%$ for drip irrigation for the low GCM). Savings in irrigation water usage could be achieved through the use of accurate and timely irrigation forecasts during the vegetation period. Looking at the current water situation in South Africa and the recent drought, farmers will have to strategically manage water. The Koekedouw Dam in Ceres, which is the main source of water for the orchards, stood at $35 \%$ of its 17.2 million $\mathrm{m}^{3}$ capacity in November 2015. Based on the findings presented in Table 4, an important adaptation strategy is to suggest a more efficient irrigation system to mitigate the impact of increased water scarcity caused by climate change. Table 4 shows that future crop water requirements for drip irrigation systems are still lower than the current water requirements under sprinkler systems. Accordingly, despite a substantial increase in water requirements under drip irrigation, the total water requirement will be less under a drip system, compared to a sprinkler system.

\section{Impact of climate change on chill unit accumulation}

Figure 2 presents the accumulated chill portion in DCP from the dynamic model for the present (1971-1990) and representative mid-century future (2046-2065) for both the low and high GCM. The calculation was done from May to August for each year of the study period. The mean accumulated chill for the present climate is 70 DCP while that of future low and high GCMs are 52 DCP and 56 DCP, respectively. Figure 2 indicates that, with increase in temperature, the accumulated chill units will reduce in the future. We observe a high level of correlation $(r=0.9832)$ between the future low and high accumulated chill units, confirming the same direction of movement for both the low and high GCM estimation.

Results from the model confirm that the accumulated chill units will reduce in the future as a result of climate change. This reduction will have a significant impact on fruit production in the study area. It is evident that farmers will have difficulty in the future in producing fruit crops that require higher chill accumulation, such as apples and pears. Other fruit crops with moderately low chill unit requirements, such as nectarines and plums, are not likely to be affected. This provides the producers with alternatives but may impact significantly on South Africa's long-term export strategy, given the contribution made by Ceres farmers. Therefore, adaptation in the medium to long term is required for future sustainability of the fruit industry.

\section{Conclusion and recommendation}

South Africa is a major exporter of fruit crops. More importantly, because of its geographical location in the southern hemisphere, it contributes to all year availability of fruit in the global market place. Deciduous fruit production is already at a marginal level; the projected impact of climate change will add more stress for fruit growers. In the case of apples as an example, South Africa is the 8th largest producer according to 2014 statistics. The country has a $6 \%$ share of the world market. Any changes in the status quo because of projected climate change will destabilise global supply with an inevitable impact on the delicate South African economy. Pressure has already been built up within the fruit industry and an effective, quick and integrated response is required to maintain market share.

It is clear that climate change will affect cropping practices in the future. Therefore, when suggesting adaptation measures to be applied to increase water use efficiency, a holistic approach that incorporates productive use of water by crop, the use of water in the root zone for transpiration and conversion into marketable product, as well as the delivery of water from source to soil efficiently, needs to be considered. In order to remain in production, farmers need to adapt to climate change stress by putting in place water resources and crop management plans. Producers must pay close attention to the usage of efficient irrigation technology as well as plant the right crop in the right place, or they must be fortified with a collection of management or adaptation tools to anticipate and address climatic disparities of cultivar and climate. Adaptation plans could include allocation of water optimally to irrigators and competing users in times of shortage, especially taking account of food security needs, and other factors relating to efficient water use. Water pricing incentives have a role to play in the framework of food security at provincial and national levels. The incentives also play a role in ensuring good quality fruits which will increase the export value and generate foreign income. 


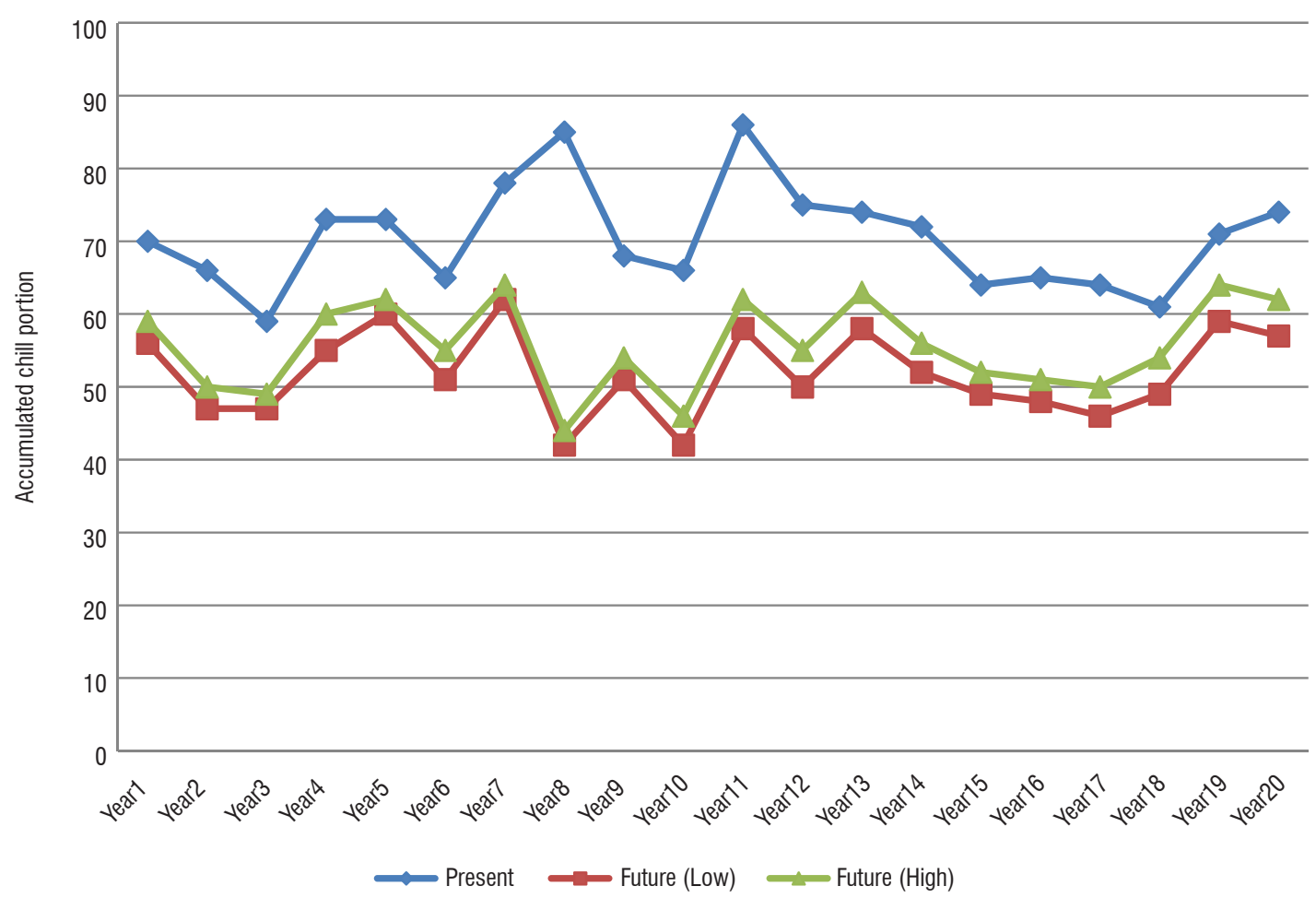

Figure 2: Comparison between the accumulated chill in the present and future climate using the dynamic chill portion model.

Breeders need to breed more drought-resistant varieties of deciduous fruits, with more rapidly responding phenologies that require lower positive chill units. This should, however, be done now because deciduous fruit species, for example, have long response times. In the short term, producers may opt to rely on the use of artificial restbreaking chemicals in cases of low accumulation. However, chemicals can, especially when applied at the wrong time, lead to phytotoxic damage to fruit buds resulting in poor fruit sets. It can also increase the production costs and hence have an impact on the profitability of such an enterprise.

The value of this study lies in its ability to offer the projected future values that will guide producers in the selection of cultivars when reestablishment of their orchards is done. It might be easier for annual crop farmers to implement management practices such as a change of the planting date or a complete shift to another variety or cultivar at will, from one season to another. In the case of deciduous fruit farmers, a substantial and long-term investment is required for the establishment of the orchards, making them more vulnerable to the long-term effects of climate change compared to the growers of annual crops. In the case of deciduous trees, once orchard managers or farmers have selected and planted their tree cultivars, they require these trees to remain in production for decades. Adaptation will likely require a transition to different species or cultivars or the development of management practices (planting density, pruning practices and irrigation regime) that can help overcome shortages in winter chill. But this adaptation needs to be anticipated years in advance. The present study offers a means of making this possible.

\section{Acknowledgements}

We acknowledge the Southern African Systems Analysis Centre, the National Research Foundation and the Department of Science and Technology (South Africa) as well as the International Institute of Applied Systems Analysis in Austria.

\section{Authors' contribution}

The study is based on 0.A.'s PhD work entitled 'The economics of climate change adaptation strategies in the Ceres region, Western Cape'. O.A. was responsible for the conceptualisation of the study, data collection, modelling and writing of the first draft. H.J. co-supervised the study and read and made contributions to the first draft.

\section{References}

1. Mimi ZA, Jamous SA. Climate change and agricultural water demand: Impacts and adaptations. Afr J Env Sci Technol. 2010;4:183-191.

2. Turner NC. Water scarcity: Challenges and opportunities for crop science. Agr Water Manage. 2006;80:1-3. https://doi.org/10.1016/j.agwat.2005.07.002

3. Luedeling E, Girvetz EH, Semenov MA, Brown PH. Climate change affects winter chill for temperate fruit and nut trees. PLoS One. 2011;6, e20155, 13 pages. https://doi.org/10.1371/journal.pone.0020155

4. Dennis FG. Problems in standardizing methods for evaluating the chilling requirements for the breaking of dormancy in buds woody plants. HortSci 2003;38:347-350.

5. Luedeling $E$, Zhang $M$, Girvetz EH. Climatic changes lead to declining winter chill for fruit and nut trees in California during 1950-2099. PLoS One 2009;4:1-9. https://doi.org/10.1371/journal.pone.0006166

6. Rana RS, Bhagat RM, Kalia V, Lal H. Impact of climate change on shift of apple belt in Himachal Pradesh. In: Panigrahy S, Ray SS, Parihar JS, editors. Proceedings of Workshop on Impact of Climate Change on Agriculture; 2009 December 17-18; Ahmedabad, India. ISPRS; 2009. p. 131-137. Available from: http://www.isprs.org/proceedings/XXXVIII/8-W3/b2/10-B10-179_ISR0\%20F. pdf

7. Linvill DE. Calculating chilling hours and chill units from maximum and minimum temperature observations. HortSci. 1990;25:14-16.

8. Reinders FB. Irrigation methods for efficient water application: 40 years of South African research excellence. Water SA. 2011;37:765-770. https://doi. org/10.4314/wsa.v37i5.13 
9. Annandale JG, Stirzaker RJ, Singels A, Van der Laan M, Laker MC. Irrigation scheduling research: South African experiences and future prospects. Water SA. 2011;37:751-764. https://doi.org/10.4314/wsa.v37i5.12

10. Van Averbeke W, Denison J, Mnkeni PNS. Smallholder irrigation schemes in South Africa: A review of knowledge generated by the Water Research Commission. Water SA. 2011;37:797-808. https://doi.org/10.4314/wsa. v37i5.17

11. Callaway JM, Louw DB, Hellmuth M. Benefits and costs of measures for coping with water and climate change: Berg River Basin, South Africa. In: Ludwig F, Kabat P, Van Schaik H, Van der Valk M, editors. Climate change adaptation in the water sector. London: Earthscan Books; 2009.

12. Louw DB, Johnston $P$, Tadros M, Schulze R, Lumsden T, Callaway M, et al. Managing climate risk for agriculture and water resources development in South Africa: Quantifying the costs, benefits and risks associated with planning and management alternatives. Unpublished project report 2012.

13. Hewitson BC, Crane RG. Consensus between GCM climate change projections with empirical downscaling: precipitation downscaling over South Africa. Int J Clim. 2006;26:1315-1337. https://doi.org/10.1016/j.scienta.2012.07.011

14. Singels A, Annandale JG, De Jager JM, Schulze RE, Inman-Bamber NG, Durand W, et al. Modelling crop growth and crop water relations in South Africa: Past achievements and lessons for the future. S Afr J Plant Soil. 2010;27:49-65. https://doi.org/10.1080/02571862.2010.10639970

15. Annandale JG, Benadé N, Jovanovic NZ, Steyn JM, Du Sauto N. Facilitating irrigation scheduling by means of the soil water balance model. Research report to the Water Research Commission. WRC report no. 753/1/99. Pretoria: Water Research Commission; 1999.

16. Van Heerden PS, Crosby CT, Grove B, Benade N, Theron E, Schulze RE, et al. Integrating and upgrading of SAPWAT and PLANWAT to create a powerful and user-friendly irrigation water planning tool. WRC report no. TT391/08. Pretoria: Water Research Commission; 2009.

17. Grove B. Stochastic efficiency optimisation analysis of alternative agricultural water use strategies in Vaalharts over the long- and short-run [PhD thesis]. Bloemfontein: University of the Free State; 2007

18. Strahler AH, Straler AN. Physical geography: Science and systems of the human environment. New York: John Wiley and Sons, Inc.; 2002.

19. Allen RG, Pereira LS, Raes D, Smith M. Crop evapotranspiration. Guidelines for computing crop water requirements. Irrigation and Drainage Paper 56. Rome: FA0; 1998.

20. Smith M. Report on the expert consultation on procedures for revision of FAO guidelines for prediction of crop water requirements. Rome: FAO Land and Water Development Division; 1991. p. 51-58.

21. Schulze RE, Maharaj M. Acacia mearnsii growth areas and yield estimation. In: Schulze RE, editor. South African atlas of climatology and agrohydrology. Pretoria: Water Research Commission; 2006.

22. Schulze RE. A 2011 perspective on climate change and the South African water sector. WRC report no. TT 518/12. Pretoria: Water Research Commission; 2012

23. Lötze E, Bergh 0 . Are chilling unit calculations still relevant for the SA fruit industry? S Afr Fruit J. 2012;11:65-67.

24. Richardson EA, Seeley SD, Walker DR. A model for estimating the completion of rest for 'Redhaven' and 'Alberta' peach trees. HortScience. 1974;9:331-332.

25. Fishman S, Erez A, Couvillon GA. The temperature dependence of dormancy breaking in plants - Computer simulation of processes studied under controlled temperatures. J Theor Biol. 1987;126:309-321. https://doi. org/10.1016/S0022-5193(87)80237-0
26. Fishman S, Erez A, Couvillon GA. The temperature dependence of dormancy breaking in plants - Mathematical analysis of a two-step model involving a cooperative transition. J Theor Biol. 1987;124:473-483. https://doi. org/10.1016/S0022-5193(87)80221-7.

27. Saure MC. Dormancy release in deciduous fruit trees. Hortic Rev. 1985;7:239-300. https://doi.org/10.1002/9781118060735.ch6

28. Luedeling $\mathrm{E}$. Climate change impacts on winter chill for temperate fruit and nut production: A review. Sci Hortic. 2012;144:218-229. https://doi. org/10.1016/j.scienta.2012.07.011

29. Linsley-Noakes GC, Louw M, Allan P. Estimating daily positive Utah chil units using maximum and minimum temperatures. J South Afr Soc Hort Sci. 1995;5:19-24.

30. Linsley-Noakes GC, Allan P, Matthee G. Modification of rest completion prediction models for improved accuracy in South African stone fruits orchards. J South Afr Soc Hort Sci. 1994;4:13-15. https://doi. org/10.1016/0304-4238(94)90077-9

31. Sheard A.G. Measuring winter chilling in the south west region of KwaZuluNatal during 2001 and its implications for deciduous fruit production. KZN Agri-report no. N/A/2002/02. Pietermaritzburg: KwaZulu-Natal Department of Agriculture and Environmental Affairs; 2002.

32. Allan P. Measuring winter chilling in areas with mild winters. Deciduous Fruit Grower. 1999;49:S1-S10.

33. Erez A, Fishman S, Gat Z, Couvillon GA. Evaluation of winter climate for breaking bud rest using the dynamic model. Acta Hortic. 1988;232:76-89. https://doi.org/10.17660/ActaHortic.1988.232.10

34. Couvillon GA, Erez A. Effect of level and duration of high temperatures on rest in the peach. J Am Soc Hortic Sci. 1985;110:579-581.

35. Erez A, Couvillon GA, Hendershott $\mathrm{CH}$. Effect of cycle length on chilling negation by high temperatures in dormant peach leaf buds. J Am Soc Hortic Sci. 1979;104:573-576.

36. Midgley SJE, Lötz E. Climate change in the Western Cape of South Africa: Trends, projections and implications for chill unit accumulation. Acta Hortic. 2011;903:1127-1134. https://doi.org/10.17660/ActaHortic.2011.903.157

37. Allan P, Linsley-Noakes GC, Holcroft DM, Brunette SA, Burnett MJ, CathcartKay A. Kiwifruit research in a subtropical area. Acta Hortic. 1997;444:37-42. https://doi.org/10.17660/ActaHortic.1997.444.2

38. Gardner RAW, Bertling I. Effect of winter chilling and paclobutrazol on floral bud production in Eucalyptus nitens. S Afr J Bot. 2005;71:238-249. https:// doi.org/10.1016/S0254-6299(15)30139-3

39. Linkosalo T, Lappalainen HK, Hari P. A comparison of phenological models of leaf bud burst and flowering of boreal trees using independent observations. Tree Physiol. 2008;28:1873-1882. https://doi.org/10.1093/ treephys/28.12.1873

40. Cesaraccio C, Spano D, Snyder RL, Duce P. Chilling and forcing model to predict bud-burst of crop and forest species. Agr Forest Meteorol. 2004;126:1-13. https://doi.org/10.1016/j.agrformet.2004.03.002

41. Hacking A. An overview of the South African low chill fruit industry [document on the Internet]. c2006 [cited 2010 Feb 14]. Available from: http://www. Iowchillaustralia.com.au/items/286/Session\%205_Hacking\%20SA\%20 Low\%20Chill\%20Industry.pdf

42. Zhang J, Taylor C. The dynamic model provides the best description of the chill process on 'Sirora' pistachio trees in Australia. HortScience. 2011;46:420-425 